\title{
Microfinance as an Instrument in Financing the Rural Sector with an Impact on Poverty Reduction and Economic Development: Albanian Case
}

MSc. Adrian Muci

PHD Candidate, Faculty of Economy and Agribusiness (AU Tirana); Email: adrianmuci@yahoo.com

Dr. Fiqiri Baholli

Professor in the Faculty of Economy and Agribusiness (AU Tirana); Email: fbaholli@yahoo.com

Prof. Dr. Drini Salko

Professor in the Faculty of Economy and Agribusiness (AU Tirana); Email: dsalko@ubt.edu.al

\author{
Doi:10.5901/ajis.2015.v4n3s1p611
}

\section{Abstract}

An efficient rural financial market plays an important role in the development and growth of productivity in agriculture and livestock. This means setting up a financial system to meet the typical functions of a market economy and above all the mobilization and allocation of financial resources to this sector and coordination with sources of donors and of the state budget. In this context, perhaps it is useful to set up a bank profiled in agriculture and rural development, ending anarchy of today and by establishing opportunities for better coverage to the growing needs of this sector. This would help for the displacement of available funds to the agrarian sector, either through a specialized bank without curb or deter the existing commercial banks, and the combination with other efforts in the form of investment funds, would constitute a good opportunity for to finance agricultural development with nonpublic resources.

Keywords: microcredit, microfinance.

\section{Introduction}

Agricultural producer's opportunities for additional financial resources over the past two decades, faced a lot of constraints which have impacts on production, farm restructuring and investments to be carried out. These restrictions are a result of a combination of factors derived from the incomplete and costly information in rural financial markets and a number of specific problems that characterize the rural sector. An efficient rural financial market, plays an important role in the development and growth of productivity in agriculture and livestock. This means setting up a financial system to meet the typical functions of a market economy and above all the mobilization and allocation of financial resources of this sector and their coordination with donors and the state budget resources. On the other hand, the construction of an institutional framework that provides funding in accordance with the request of the rural sector is a necessary condition for the efficiency of the funding in this sector. Expansion and well-functioning farms and other agricultural activities, requires more than natural resources, requires financial resources to make these natural resources more efficient. Of the two main sources of capital, external and internal, domestic funds are the most important component. In most countries with low incomes and especially in periods of transition, financing through microcredit ${ }^{1}$ is dominant in the rural sector. Micro-credits granted to the rural sector, primarily aimed at reducing poverty and at a later stage the development of farmers economies affecting the pace of GDP growth in the sector.

In Albania already for more than two decades functions the microcredit market in the rural sector, with a dual economic and social impact; farm family poverty reduction and development and consolidation of farmers economies. One of the key monetary resources that would meet a substantial portion of funding for agriculture, are the savings of this

${ }^{1}$ The concept of microcredit was developed extensively for the first time by Muhammad Yunus, Nobel Prize winner in economics and founder of Grameen Bank, Bangladesh 
sector itself. In this context, we think it is important that at the current stage of development in the rural sector should be targeted by intensive transfer of the microcredit system in the microfinance system. Microfinance means in addition to microcredit, the implementation of a range of financial services for the rural sector dealing with the mobilization of savings and the provision of other services that characterize a rural financial market. So, microfinance can be defined as the provision of financial services to small entrepreneurs in the countryside that are farmer's economies. It combines research profit motive with social development priorities of these economies.

\section{Methodology}

The realization of this paper is based on secondary qualitative and quantitative data, within the market of microcredit. All this paper identifies the problems of market performance and microcredit in rural sector and the impact of this form of financing in the sector. Also, the historical experience of the financing in the rural sector gives us the opportunity to do a thorough analysis, so to give some recommendations for the development of rural financial market in the future, and especially the most appropriate organizational model of the rural financial institutions. This work is conducted with a focus on farm economies, where Albanian Saving and Credit (ASC) Union it operates as microfinance institution.

\section{Analysis of Microcredit in Rural Sector}

Many years ago, at the beginning of transition of the countries of Central and Eastern Europe towards a market economy, the vision to transform the agricultural sector was summarized with the idea of Jacques Attalia that three things were necessary "... for the transformation of the socialist village into a capitalist village, agricultural cooperatives, loans from banks and insurances ..." ".Now, after nearly a quarter-century from the beginning of that process, looks like that reforms in the Albanian economy, failed to properly coordinate these three key ingredients to have a modern agriculture. Meaning an agricultural sector that has access to sufficient financial resources, able to benefit extensively from grants and pre-membership funds in the EU as well as a sector that possesses the necessary capabilities in meeting the EU standards, that means to be transformed into a sector with sustainable development that guarantees growth of the competitive skills of farms and agro-processing operators of the country. In recent years, efforts have been made to support the agricultural sector. This happened as indirectly through investments in rural infrastructure, as well as directly, through initiatives and regulatory incentives including the adoption of a specific law, as was the law for the establishment of agricultural farms (2014).

The development of the agricultural sector in market economy conditions, required and requires financial support to carry out necessary investments. Demand for loans from the agricultural sector has been and is high (Salko, 2013). Individual farmers require access to credit in order to purchase inputs and equipment, to meet the expenses for the establishment of greenhouses, processing factories of agricultural products and livestock, building vineyards or fruit trees etc. For meeting the demand for loans in the rural sector, there are three main providers of financing; Banking System, Financial Institutions of Microfinance (FIM) and various donor projects. The small size of the farmers economies, means that providers of funding for them, grant microcredits but their average amount has had growing evolution over more than last two decades. Now, the average amount allocated to an farmer economy ranges from 20,000 to 50,000 All in the first years of transition, in 300,000 to $2,000,000 \mathrm{ALL}$ in recent years, reflecting the demand for the realization of investments in order for these economies to reach markets .

\subsection{Microcredit banking market}

Although the banking system is the most developed segment of the financial system of the country, should be recognized that the financing of the rural sector and particularly farmers economies, has been low or negligible. If we refer to indicators of credit-granting by the Albanian banking system of the rural sector, it has historically been $0.9 \%$ to $1.7 \%$ of the surplus credit accorded overall by this system. Among the reasons for not lending to farmer's economies by commercial banks, we can highlight:

- Lack of institutional capacity of commercial banks, because of the high costs that have small loans. Commercial banks consider the activities of small farmers economies and consequently, lending to them costly.

- The small size of farms and their insufficient income, restrain t the absorption of formal investments in the agricultural sector and in sectors associated with it. 
- Relatively high rates of interest (due to very high premium for credit risk) are a prohibitive factor. Small farmers cannot repay the loan with commercial conditions offered by the Bank. This results from the practice so far, as well as the conclusion drawn from the survey of the farm budget.

- Banks do not engage in lending in agriculture, because they consider farms as discontinued activities and not very durable. This trend is also a result of the displacement of rural families to urban areas.

- Smallholder farmers often lack collateral to meet bank requirements. Malfunctioning of the land market is a relatively large obstacle for lending, because the earth still not preferred to be served as collateral.

- The lack of banking infrastructure in the rural sector, that is seen in the non- scope of activity of banks in this sector.

However, a trend of recent years is that the banks are also getting more active in the market of microcredits (such as Bank ProCredit Bank Credins, Raiffeisen Bank and National Commercial Bank) despite their small interest in this regard. This can be explained by the narrowing of market competition and the need to explore new investment opportunities ${ }^{2}$. Now, an increasing proportion of the amount of credit goes to small businesses, which often helps them in the initial stages ${ }^{3}$. Banks are particularly more active in micro financing in urban areas where operate consolidated agribusiness economies and with huge capacities that can be considered as agro-processing industries. On the other hand, we must emphasize that thesmall agro-processing businesses lack financial support from banks.

\subsection{Financial microfinance institutions.}

In Albania for many years, operate a number of non-bank financial institutions, the role of which is dominant in the microcredit market. These non-bank financial institutions often have their origin from donors projects that have allocated funds for financing in Albania and later are transformed into financial microfinance institutions.

Unlike the banking sector, non-banking and micro credit sectors are more willing to give micro-credit to small and micro enterprises, start-up businesses as well as individual loans to farmers. Conditions for micro financing by these institutions are estimated to be easier compared with bank credit terms for small businesses. Loans offered by these institutions are mostly short-term, in local currency and the payment of installment coincides with seasonal income of farmers / rural businesses. The loan portfolio of these institutions has a broad geographical distribution and in rural areas in the agricultural and livestock sector of the local economy.

In Albania, in addition to several banks that offer micro-loans (ProCreditCredins and Raiffeisen), there are many micro-financing companies and some small microfinance institutions in the form of social organizations, unions, associations. According to the classification of the Bank of Albania, micro-finance institutions can be classified according to the economic activity in: a) non-bank financing institutions (NBFIs) and b) savings and credit associations (SCA). In December 2014, the Albanian NBFIs held a gross loan portfolio amounting to 19.68 billion ALL, reduced by about 360 million ALL or $1.8 \%$ compared with the end of 2012. The loan portfolio of NBFI States constituted about $3.49 \%$ of the portfolio loans to the banking system, remaining the same compared to 2012. Meanwhile, the gross loan portfolio of the SCA network, is estimated 4:36 ALL billion, but has declined to 4.8\%, compared with 2012. Credits of ASC Union account for about $0.77 \%$ of loans in the banking system. Membership of SCAs reached the number of 121 associations and 51.291 members across the country.

Table 1: Gross loan portfolio

\begin{tabular}{|c|c|c|c|c|}
\hline IMF & 2011 & 2012 & 2013 & Borrower 2013 \\
\hline FAF-DC & $21,009,663$ & $21,585,482$ & $20,623,566$ & 3,836 \\
\hline ASC Union & $35,547,681$ & $35,857,479$ & $19,841,683$ & 15,355 \\
\hline BESA & $41,467,853$ & $47,280,837$ & $53,361,390$ & 26,526 \\
\hline NOA & n/a & n/a & $39,653,364$ & $15,266^{*}$ \\
\hline Vision Fund & $2,045,368$ & $2,264,384$ & $2,262,626$ & 2,098 \\
\hline Total in \$ & $100,070,565$ & $106,988,182$ & $135,742,629$ & $\mathbf{6 3 , 0 8 1}$ \\
\hline
\end{tabular}

*2010 Data

\footnotetext{
2 Bank of Albania 2014

${ }^{3}$ Annual Report of the Bank of Albania 2014
} 
The structure of the loan portfolio remains concentrated in business lending (91.2\%), and mainly in the sectors of "trade, repair of motor vehicles and household items" 30\%, "Agriculture, hunting and forestry", 11.8\%, and "sectors other ', $14.6 \%$. Total loan portfolio is dominated by lending in leke, accounting for $60.1 \%$, which is primarily focused on lending and microcredit institutions. ${ }^{4}$

Of all MFIs mentioned above, only ASC Union and FAF are mainly focused on the micro credit market in the rural sector but in relatively assigned segments. ASC Union operates mainly in the most intensive areas of agricultural sector (Shkoder, Lushnje, Fier, Durres, Tirana, Vlora, Elbasan, Berat, Korca, etc.), while the FAF operates primarily in the northeastern areas and southern mountain areas, but in recent years is also extended to other districts. During the last 56 years, these institutions have regulated credit policy aiming not only to support farmers with small amount of loans, but also their financing ventures that aim to reach markets with their products.

In rural market, MFIs feel little competitiveness of banks, because they offer very high interest rates that go up to $25 \%$, while micro-credit companies offer interest on level $16 \%$. In addition, banks have always numerous bureaucratic procedures and multiple requests for documentation. Also, banks require guarantees for their loans, while MFIs not.

\subsection{Financing through various projects with donor funds.}

An important source of funding for farm economies have also been allocated funds from different donors (World Bank, EBRD, USAID, FAO, GTZ, etc.). Multiple projects with donor funding are realized either as separate components or through cooperation with the Ministry of Agriculture and Food (now the Ministry of Agriculture, Rural Development and Water Management). Suffice it to mention the project implemented by this Ministry that of "Competitive Grants" that funded many enterprises in agriculture, the effects of which have already started to yield its fruits. However, these funds have been segmented and not coordinated with all levels of development of this sector.

\section{Microfinance as an Important Direction of Establishing Rural Financial Market}

Microfinance is becoming an integral part of a country's finances. No wonder that microfinance has gained a high growth rate: about 10,000 institutions across the world are involved with it. Yet they are very different in terms of size, legal structure and vision. However, 3 are the most prevalent trends and most promising that associate the success of this new industry, strengthening it structurally:

- Microfinance institutions are involved in generating funds from commercial sources as a way to strengthen their long-term sustainability. Even in Albania MFIs are using this source of financing to expand their activities.

- Microfinance industry requires more and more specialized expertise and financial knowledge. The fact is that the staff of the IFM in Albania is specialized in the microcredit market in order to enhance the performance of these financial institutions.

- Microfinance is growing and is becoming a transparent and regulated industry. All IFM in Albania already subject to the rules of licensing and supervision by the Bank of Albania, thereby serving their consolidation. The recent involvement of the two Albanian Savings and Credit Unions in the deposit insurance scheme constitutes an innovation in this direction. This provides a solid legal, financial and political structure, to support their growth and sustainability.

The development evolution of IFM in Albania does not mean that microfinance is shifting its focus from poverty alleviation, on the contrary: commercialization expertise and regulation are tools for improving the level and quality of the impact of the socio-economic situations of the micro entrepreneurs and their families.

Microcredit has helped reduce poverty in many countries in the world, but also in Albania. Microfinance in our country began to find ground since the end of 1992, under a program to alleviate poverty in the rural area. Consolidation through the years of these programs enabled the country today to successfully operate some microfinance institutions as "ASC Union," "BESA", "First Society of Financial Development" (FAF JSC), "Union echoes" etc. The microfinance sector is already an integral part of the financial sector in Albania and year after year has shown growth. A positive development in the microfinance market that is worth mentioning is the low level of non-performing loans in relation to the banking system. According to reports of MFI, portfolio at risk results between $8 \%-12 \%$, while in the banking system, the level of non-performing loans has reached nearly $23 \%$. 
Albanian Savings and Credit Union (ASC Union) own the largest part of the portfolio of micro credit to the rural sector. Feature of this institution is that, based on the principles of cooperation along with the farmers micro-credit financing, attracts their savings in form of deposits. Therefore, this institution can be considered as the ' bank of the village ' and offers this financial service to farmers that are members of the union. At the end of 2014 this institution, which occupies about $30 \%$ of the total micro credit market in the country and the biggest part of the micro credit agricultural market, extends its activity in 1,100 villages. At the end of this year, the loan portfolio of ASC Union was ALL 3.7 billion and total deposits of saving resulted around 2.6 billion ALL.

Experience shows that microfinance can help farmers to increase their economies income, build viable businesses, and to limit the risks. Based on a survey conducted with farmers of the areas where ASC Union operates, can be verified the fact of increasing revenue from their economies as a result of funding from this institution. During the implementation of interviewing farmers, they relate their income by the number of years as a member of the ASC Union.

As shown in the figure below, members with a long history as a borrower in ASC Union in years have provided higher income in years, thisas a result of the investments realized. The long experience as members of the ASC Union has given them opportunities and facilities in borrowing after earning the trust from their institution. As a result of a long membership, a stronger relationship and higher trust between the client and the financial institution is built.

From Fig. 2 hereunder, we note that farmers who are members for 3 years have their incomes in a lower level,on the average 300.87 USD per month. A 4-year member has higher income with an average of 364 USD per month, but still less than those who have a membership of 5 years, which get 494 USD per month. While a member with 10 years history, has a monthly income higher than 645.8 USD (to be considered as sufficient not only for survival). As shown in the figure, revenues increase with years of membership, because over time, production improves, has a higher output. Furthermore, farmers are able to expand their activities by buying another piece of land or simply investing in machinery or equipment. Having higher incomes allows farmers to pay the loan faster than 3 years and why not apply to get another loan.

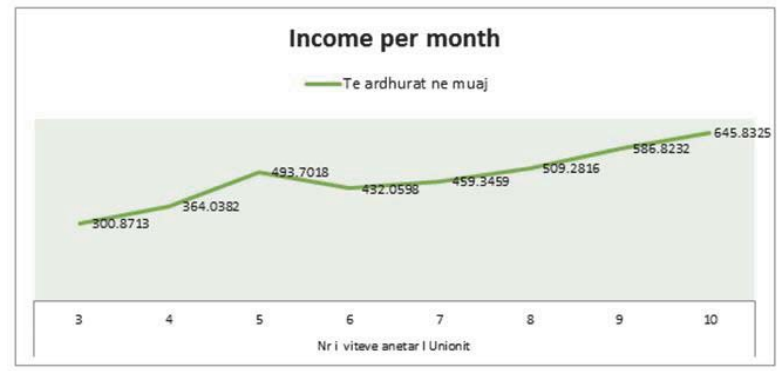

Figure 2: The level of income per month compared with the number of years of membership Source: ASC Union

Also, there is a relationship between income per month and the number of loans taken which shows that over the years, the number of loans taken, increases by providing higher income and better economic opportunities. Fig. 3, explains the number of microcredit impact on the income of farmers.

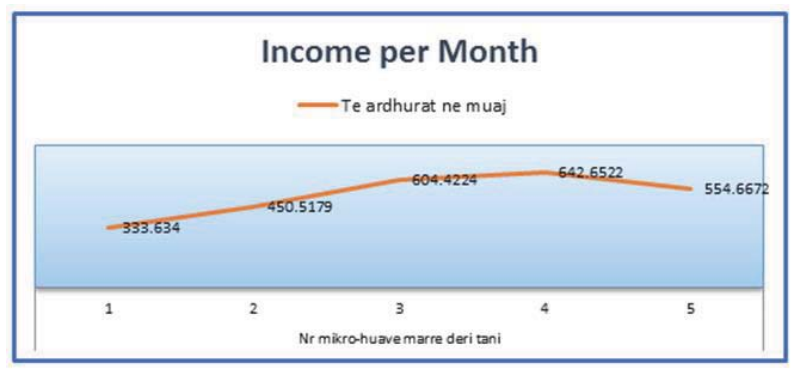

Source: ASC Union 
As shown, the increase in revenues shows that the number of loans taken positively influences the level of income. Farmers who have taken a loan so far, have an income on average 333.5 USD per month and those who have taken two microcredits have an income of 460.5 USD per month, which makes a difference of 130 USD per month more.

With the increasing number of loans, the income curve increases and reaches an income 642.65 USD per month. Suddenly the curve drops to 564.6 USD per month, which makes what we said above insecure.

Currently, the development of microfinance as an instrument in rural development requires the implementation of two short-term objectives:

At first, increased funding through loans subject to the implementation of investments in farmers economies to produce for the market. This requires increasing the interest of commercial banks to finance in agriculture to the farmers economies. Their financing experiences of agro-processing ventures make necessary the financing of raw materials providers for the industry, who are farmers economies. Given the current stage of problems that banks have related with the high indicator of non-performing loans, lending in agriculture faces a high risk. For this reason, increased interest of banks to finance the rural sector necessitates the application of schemes that reduce risk in lending to agriculture. Based on the practice of financing of SMEs should be encouraged and accelerated government initiatives for the creation of this scheme through the Credit Guarantee Fund. This fund will serve as a guarantee for banks in case of failure in their funding, covering a portion of the risk. In addition, we think that there should be established a central structure with a focus on the financing in rural sector that will coordinate this financing in the basis of policy and strategy development and medium-term agricultural development, already drafted.

Secondly, it is required that in this period innovations should be established in financial products.Innovation of financial products including financial services that have not previously existed in the market or differ substantially from existing services. Innovations in the product can be used to better reflect the demand of rural customers to improve efficiency or to expand the activity of the organization. They can be very important in ensuring the existence of financial institutions. A flexible and acceptable model of the deposit and loans allow farmers to cope with seasonal and unpredictable flow of income. The motivation of farmers to seek financial services is a function with many factors. An innovation in the product is for example the establishment of a flexible palliative savings service in rural financial institutions. National institutional needs of mobilization of domestic resources have been the basis for the initiation of development programs of financial rural markets to exploit savings. Deposit mobilization as an integral part of rural finance programs for the poor can be an important element to improve their capital situation and earnings. (World Bank).

If we analyze the income and savings of the rural sector, we see that this sector has sufficient capacity savings that if being used in this sector would afford large investments. According to the main channel of insurance of monetary tools we would rank, firstly, remittances and, secondly, monetary tools provided by the sale of surplus products, mainly livestock and agricultural. A very important indicator that emerges from the study is that about a quarter of monetary income,represents the free money that the rural family keeps at home or deposited in the bank.

Free monetary instruments of rural economies to a certain extent are not put in the banks in the form of deposits. An efficient way of using the rural savings in addition to ASC Union mobilization is the possibility of co-finance of investments of farmers economies. Thus, commercial banks and IFR to co -finance investment projects that would be more effective, because it would combine the interests of lenders and borrowers.

Both these directions will cause a full and definite transition from micro lending to micro financing as an instrument that reduces poverty and develops the rural section.

In this context it might be useful the establishment of a bank that is profiled in the agriculture and rural development of the country, ending in this way today's anarchy and creating opportunities for fulfilling as much as possible the needs of this sector. This would be enough to shift the funds towards the agriculture sector, through a specialized bank without deterring and hindering the existing commercial banks, as well as through the combination of other efforts in the form of investment funds and these will constitute in a great opportunity to finance the agriculture sector with nongovernmental sources. The establishment of a specialized bank, including also the private capital within, will create conditions for the Albanian agriculture to become a sector with great development opportunities which will absorb the right financing values. The access of capital and the lack of technical knowledge are two of the main reasons which prevent the absorption of funds from this sector and a specialized bank would contribute in this direction.

\section{Conclusions and Recommendations}

$\checkmark$ As the result of the analysis of these founding it is concluded the role of microloans/ microfinance as an important instrument for the development of the opportunities for the rural section, increase the standard of 
living for farmers, their income, productivity and expansion of their activity, whom otherwise would not have access in financial recourses.

$\checkmark$ Farm economies are in a great need for loans. By now many of them have overcome the survival faze and are looking for loans to invest. The main objects for loans are investments in *horticulture, arboriculture, greenhouses, building of warehouses and stalls, as well as activities for the processing of animal products.

$\checkmark$ The banks do not show any real interest in famer's loans. They are more focused in lending to businesses mainly located in urban areas. The positive developments of the last years must be encouraged.

$\checkmark$ The number of IFM in the rural sector is limited and the ASC union takes the most space in the microloans market and almost $95 \%$ of the mobilization of rural savings from these institutions.

$\checkmark$ Farmers encounter a lot of difficulties in selling their products because of the lack of an established market and the low prices that are a result of the competition from the imported products. This happens especially during the production peak periods. The investment in building small an middle greenhouses it a way of confronting the competition from imported products.

$\checkmark$ In order to low as much as possible the risk of loans failure in the rural section it is necessary the operation as soon as possible of Credit Guarantee scheme through the Credit Guarantee fund, which is an initiative that should be undertaken by the government.

$\checkmark$ It is necessary the further institutional consolidation of USHKK and the USHKK network through: 1. Increasing efficiency and improvement of financial indicators of this institution; 2. Increasing the varieties of financial services with the goal to increase the inside financing sources (members savings) and increase the lending to support the business investments of farmers, though raising the amount of loans and their maturity term.

$\checkmark$ The support with financial sources for the clients investments will increase the incomes from agriculture as well as other activities performed in villages. This lending policy should give priority the new and potential members of SHKK.

$\checkmark$ The support of farmer with loans should aim primarily the production growth for the market as a possibility for the quick development of the standards of living.

$\checkmark$ Beside financing the two main sectors such as agriculture and animal raising, another priority should also be financing the building of small greenhouses. The activity development in these directions will give high results if the marketing network functions well.

$\checkmark$ Priority in the future lending should have the farmers investments and as a result the maturity term of these loans should be longer and the sum higher.

\section{References}

A.Fuentes, G. (1996). The Use of Village Agents in Rural Credit Delivery. Journal of Development Studies, Vol.33.No.2

Buckley, G. (1997). Microfinance in Africa: Is it Either the Problem or The Solution, World Development, Vol.25.No.7

Swinnen, J. Gow, H. (1998). Agricultural Finance and Institutional Reform in Transition Economies. Working paper

Flavingny, P. (1951). Credit Agricole Mutuel en France.

H.J.Bol. H. The Cooperative Banking System in the Netherlands.

World Bank. (1993). Report and Recommendation on a Proposed Agriculture sector Adjustment Credit

Banka e Shqipërisë. $(2010,2011.2012,2013,2014)$. Raportet vjetore.

USHKK (2010,2011.2012,2013,2014). Raportet vjetore.

International Fund for Agricultural Development. (2000). Rural finance, from unsustainable projects to sustainable institutions.

KfW Entwicklungsbank. (2007). Microfinance in the Service of Poverty Reduction. 